\title{
Global Investment Governance: A Call for Greater System Diversity and Rule Uniformity
}

\author{
Jiawen Cui \\ China University of Political Science and Law, Beijing, China \\ Email:mlbsabc@sina.com
}

How to cite this paper: Cui, J. W. (2020). Global Investment Governance: A Call for Greater System Diversity and Rule Uniformity. Beijing Law Review, 11, 614-625. https://doi.org/10.4236/blr.2020.112037

Received: April 15, 2020

Accepted: June 20, 2020

Published: June 23, 2020

Copyright ( 2020 by author(s) and Scientific Research Publishing Inc. This work is licensed under the Creative Commons Attribution International License (CC BY 4.0).

http://creativecommons.org/licenses/by/4.0/

\begin{abstract}
Investment liberalization and economic cooperation between countries assured the steady growth of FDI. However, the turbulence of the 2007-8 economic crisis increased risk for overseas investment, prompting many countries to "go it alone". The crisis highlighted systemic tensions that the current neoliberal global investment regime seems unable to resolve, sowing discord among countries dependent on global investment for growth and development. This paper begins with the fundamental observation that the world has moved on from 1945 and posits that the first half of the 21st century should witness the gradual, managed formation of a new global investment framework. Governance theory should make contribution to the stability and predictability of global economy as it does in the global trade regime.
\end{abstract}

\section{Keywords}

Globalization, International Investment Governance, Diversity, Uniformity

\section{Introduction}

Over the past half century, global investment has been serving as the foundation of global and regional value chains, as well as an engine for the growth of global trade. However, subject to ramifications of global financial crisis and economic cycles, global economy has shown modest signs of recovery despite relief in the economic downturn. In 2019, foreign direct investment across the world has dropped by $13 \%$ to $\$ 1.3$ trillion (Zones, 2019), marking the third year of decline in a row. In the meantime, mounting instability factors like geopolitical risks, trade protectionism and unilateralism have sent the global economy in a mixed state of volatility and relief.

The governance structure promoting and regulating foreign direct investment (FDI) has been recognized as an important component of stable, predictable 
global economic growth (Globerman \& Shapiro, 2002). A relatively sophisticated governance system for international trade and finance has been established in the last round of economic leap. The current global investment regime is mainly comprised of investment related provisions under the WTO framework, over 3500 bilateral investment treaties, hundreds of free trade agreements, regulatory laws and provisions of various countries on foreign capitals and investment dispute settlement mechanisms centering on investor-state dispute settlement (ISDS). Economic crisis has caused turmoil in the field of global investment, resulting in further enhancement of the risks of overseas investment. The fact that global investment is an area where economic, political, ecological and other global issues are most concentrated undoubtedly increases the difficulty to apply global governance concepts like "good governance" and "cooperation" in this field. Compared with the governance of global trade and finance, global investment governance has not been systematized in practice, which is a fact that should not be animadverted, for global investment is naturally "fragmented". Leading authorities agree that the central goal of global investment governance should be the maximization of investment outcomes (for both investor and beneficiary) without regard to such matters as state, race, ideology, religion or economic development level (Cooper, 2004). The existing global investment regime, however, does not entirely achieve this goal. The neoliberal system of trade and investment marketization, established under the Bretton Woods framework by mainly developed countries towards the end of World War II, placed developed countries, such as the U.S. and UK, in a unitary role as net capital exporters. The global investment regime-which they primarily created-mainly reflected the desire of these developed countries to provide sophisticated protections for investments in developing countries with relatively weak financial and judicial institutions (Haggard \& Simmons, 1987). To attract foreign capital and to develop their own national economies, developing countries were forced to accept a mechanism unfairly favoring the investor (Henkin, 1970). This "investor favoritism" caused an imbalance of rights and obligations between investors and host countries. Such a trilemma has proved to be more prominent in the post-crisis era. Luckily, in comparison to the failure of other uni-disciplinary theories like the "north-south conflict", "commercial arbitration" and "domestic public law" in international investment (Xu, 2010), a sound global investment governance regime is still of great significance for coping with the internal paradoxes of the current global investment regime and analyzing the development trend of global investment. Today FDI is an underperforming, underutilized driver for global economic growth.

Although there still hasn't been a broadly accepted definition for global investment governance, however, according to the leading theory, the global investment governance should at least contain the following three elements: 1) the widely accepted value goal of the investment governance, 2) the reasonable rights to participate in the international investment governance among of all the participants (sovereign countries, international organizations, intergovernmen- 
tal cooperation, etc.), 3) the applicable rules and norms for managing the global investment order (Barnett \& Duvall, 2004).

This paper begins with the fundamental observation that the world has moved on from 1945, with many formerly developing countries now sophisticated sources of substantial outbound investment. Political, economic and judicial reforms that swept through much of the developing world transformed economies, while also imposing painful costs in such areas as the environment, labor relations and sovereign-state governance rights. These reforms rightly accorded some developing countries more discursive power in the global investment governance conversation. So, just as the second half of the 20th century gave birth to a neoliberal global investment mechanism, this paper posits that the first half of the 21st century should witness the gradual, managed formation of a new global investment framework, as developing countries reject the "control" imposed by the old mechanism - and as developed countries progressively adjust the goals that they had once pursued, but are now largely working against them.

\section{The Value System of the International Investment Governance: Toward a More Polycentric Model}

\section{1) The collapse of the "laissez-faire capitalism" value system}

Developed countries dominating the current global investment regime have awoken to the changing environment and have started to reevaluate aspects of that regime in an attempt to correct the imbalance of rights and obligations (Keohane, 2001). For example, in the 21st century, capital exports are no longer monopolized by a handful of developed countries. Highly favorable treatments once designed solely for investors from developed countries have now fallen into the hands of investors from developing countries, such as China.

The multiplication of bilateral and regional investment agreements has exhibited an evident "spaghetti bowl effect", and an increasing number of developed countries, rather than developing ones, prefer to "acting alone" or "ganging up", seeking to talk fewer responsibilities while obtaining more regulatory power at the multilateral level. Further developments taking place in civil societies of developing countries have affected governmental decision-making. The negative impacts of international organizations and multinational corporations have been increasingly prominent as they become more sophisticatedly developed. The financial crisis has further complicated the economic, social and even political relationships between host-country governments and civil societies, foreign investors and host countries, host countries and home countries, and international organizations (including international organizations for dispute settlement). As a result, the neoliberal globalization is being rejected by its creators in the 21 st century.

2) Remolding the value system-toward a more polycentric model

Countries with similar development levels, cultural orientations and political stances are more likely to work together to pursue shared interests (Hoffmann, 
2002). By independently_or in concert-selecting favorable development modes and establishing similar governance systems, these countries stand to exert greater impacts amid the global political and economic restructuring. The existing global investment regime which advocates neoliberalism, absolute liberalization and marketization of trade and investment in the world, was established, dominantly, by developed countries after World War II. Developed countries had long been playing a unitary role as capital exporters. Therefore, the global investment regime at that time mainly reflected developed countries' intention to provide sophisticated and advanced protections for investments in developing countries implementing relatively backward judicial systems. "Investor favoritism" was the core value of global investment during this period that has lasted up to date. To attract foreign capitals and develop their own national economy, developing countries have been forced to accept such mechanism. Neoliberalist policies have made contribution to economic prosperity in the Western world, resulting in the rapid growth of the global economic growth in the past 50 years. On the other hand, systematic progress including politics, economy and domestic judicial systems had also been achieved in developing countries during this period. Although such value system imposed painful costs in areas like environment, labor treatment and sovereign-states' regulatory power on many developing countries, it has helped developing countries establish their economic foundations so that they could gain more discursive power in the following global stage.

As it can be seen, Recent years have witnessed the establishment of an increasing number of influential international actors like the "Group of 77", the "Group of Eight", the "BRICS" and the "G20" that play a crucial role in dealing with global issues and seeking new, shared frameworks for global investment. The paths to global economic integration have clearly changed.

Some scholars warn that regionalism and "groupuscules" may inhibit the progress of global integration (Hoekman \& Mavroidis, 2015). However, respecting diversity and acknowledging the validity of different values is the only road to the development of international community, given that the sheer diversity of development levels, political and economic systems, cultures and religions. In the meantime, such multinational organizations as the WTO, UNCTAD, OECD, and major players like China (proposing the International Investment Framework on G20) and the EU (multilateral investment court), strive to advance greater economic globalization despite the obstacles encountered in the post-crisis era.

Just as the 20th century had given rise to a global investment mechanism that was a product of neoliberalism, the 21 st century has seen a gradual formation of a new value system of global investment as developing countries started to resist the "control" imposed by the old mechanism and developed countries progressively adjusted the value that they had once advocated but ended up working against them. In the 21 st century, capital exports are no longer monopolized by developed countries. Highly favorable treatments once designed for investors 
from developed countries have now fallen into the hands of developing countries to counter against them; the original creators of the value for global investment have also started to reevaluate them in an attempt to correct the imbalance of rights and obligations in the value system through a series of policies in order to cope with changes in global economic and political situations.

Although economic recovery in the post-crisis era still relies on cooperative operations and efforts at a global level, the time when a few countries were able to establish and promote a paradigm for the value of global investment has gone. The value system previously guiding global investment (profit maximization) has broken through to a new era of elevated and diversified values. Now contending with the values of yesterday are such new measurables as the impact of investment behavior on security and citizen well-being; whether investment behaviors promote equality and sustainability, protect resources and cultural heritage, and combat corruption (Alonso \& Ocampo, 2015). The rise of China, in particular, highlights the need for a new system that forges common economic ground amid disparate political and economic values and rising ideological diversity (Kupchan, 2012).

Although common cause in global investment is more easily achieved among regional or interregional players, by no means should these combinations become an excuse for trade protectionism and geopolitics. The next leap forward for the global economy can only be achieved by sharing experience between different value systems and converting the diversity, differences and complexity into vitality and impetus for common development.

\section{The Actors of Global Investment Governance: Toward Greater Diversity}

1) The "decline" of sovereign countries in the field of international investment

Sovereign states are the most fundamental actors in today's global investment governance regime. Countries address their interests through discussions, negotiations and various forms of cooperation, such as participating in cross-border investment dispute resolution agreements and supporting changes to their domestic judicial systems. Some scholars assert that the past century has witnessed the "decline" of sovereign state (Cassese, 2012). Cassese used the term "dethronement" to describe the process by which sovereign states have increasingly restricted by international laws (Beaulac, 2003), while other scholars referred to the process as a "leaving" (Alvarez, 2011). Yet the behavior by which a country voluntarily accepts the restrictions imposed by international laws in order to maintain the global public order (and thus obtain a stable external environment for development) is usually considered more an act of implementing, rather than abandoning, sovereignty (Cai, 2018). Given the unique characteristics of global investment, the degree to which a country has "left" or opted-out of in the global investment framework has more profound implications when compared to other areas of international relations. Developed countries have led the "leaving" 
process. They have, for example granted private investors the right of action through investment agreements, which promoted individuals' status in international laws and thus caused, in an objective manner, the "leaving" of the countries in the global investment regime. The proliferation of rights brought about by "leaving" has caused a crisis of legitimacy and effectiveness in the global investment governance system (Zakaria, 2013).

It should be noted that although we stress here the "leaving" or opting-out by counties, we confine our analysis to the area of global investment rather than other areas of international law. Sovereign countries remain at the absolute "center" in global investment governance, even if they choose to grant more rights to investors. Non-state actors, including international government organizations, informal global civil society organizations, NGOs, multinational corporations and even influential individuals, are still playing an auxiliary role to state actors in the modern global investment governance system. The power of each actor participating in global investment governance corresponds to its capability, and each performs its own functions.

2) Redistribution of power in international investment governance-toward clearer boundaries

Emerging countries, such as China, now lead the growth of the global economy (Stephen, 2014). These emerging economies and other countries in the developing world are re-evaluating the burdens and benefits of the current regime. Whereas developing countries once opted-in to the system in order to attract inbound investment to grow their domestic economies, these same countries, having developed their economies, their civil societies and judicial systems, are now looking to rebalance their relationship with the global investment community. The enhanced civil, political and economic strengths of these countries have prompted their governments to reevaluate the risks to their sovereignty represented by executed investment agreements. Such steps prompt these countries to more actively participate in global investment governance, with a view to promoting the restructuring of the global investment regime.

Non-state actors, especially global investment dispute settlement institutions, have accorded a lopsided emphasis on the protection of investors. While there is no doubt that these institutions were a product of the global investment regime designed for protecting investors, such as one-sided protection, along with the rise of multinational corporations, has contributed to the further decline in influence of countries, including developed countries, over the global investment regime (Strange, 1996). Developed countries that had long touted neoliberalism are now finding themselves deeply restricted by this "golden corset" due to the changes in global capital flows (Alvarez, 2011). They are reduced to being frequent defendants in investment arbitration courts, or even victims of the rules they have created by themselves. In sum, a shift of roles has occurred between the developed countries that had touted neoliberalism and the developing countries that had implemented trade protectionism since the outbreak of the economic crisis. 
The 2007-8 economic crisis further intensified conflict between many of the actors in global investment governance. These include sovereign states (host and home countries), sovereign states and investors, sovereign states and international organizations (global investment dispute settlement institutions), and sovereign states and civil societies. In response, the international community-initiated reforms to the "teeth" of the international investment agreements-the global investment dispute settlement mechanism-in order to rebalance the status of various actors. The options proposed by various parties on reforming the investor-state dispute settlement (ISDS) mechanism, as disclosed by the UNCTAD, exposes the diversity of stances held by these parties (UNCTAD, 2017).

Moderate reformists led by the U.S. emphasized that the control of sovereign states should be enhanced within the existing ISDS framework through measures like narrowing the definitions of investors and investment, highlighting the interpretive power of contracting countries, weakening the jurisdiction of arbitration courts and ensuring the "security rights" of nations. Such measure would, of course, maintain the dominant position of the "American mode" in the global investment regime. The EU-led radical reformists, however, attempted to enhance the direct role of states in dispute settlement mechanisms through a multilateral investment court where "state"-related problems are judicially resolved by the states themselves instead of third-party institutions. Other players pursuing a multilateral model also include China which is actively implementing the G20 International Investment Framework and seeking to perfect the dispute settlement mechanism for investments based on the "Belt and Road" initiative (Sauvant, 2017).

Brazil, Australia and India opted for an abandonment of the ISDS mechanism and a return to the local remedy model, which is what they are actually doing (Schreuer, 2005). The status of other actors is also changing. Some non-governmental organizations have gained increasing influence and are more likely to stand together with sovereign states in pursuing the return of states and protecting the demands of civil societies on issues like environmental protection, labor treatment and sustainable development by setting out definitive recitals and general exception clauses in newly executed agreements (Hewson \& Sinclair, 1999). Global investment dispute settlement institutions have also begun reforming themselves after realizing that the excess expansion of their power has drawn broad criticism. Private investors have shown their willingness to shoulder more responsibilities for global investment in order to obtain more investment opportunities under the new international situation.

The chief actors of global investment governance, in sum, are heading in the direction of greater diversity. This is manifested by the diversity of sovereign states-regardless of their status as either developed or developing countries-seeking a return in the post-crisis era. The "polarized" model dominated by the group of developed countries has been gradually broken by the rise of emerging economies. The rise of developing countries necessitates the adjust- 
ment and restructuring of global investment rules that were established after World War II, and ideally, creates a "diversification" of sovereign countries. The global investment governance system in the new era is arguably a system that is formed through the competition of multiple power centers, as well as the competitive models they represent, in an environment of greater equality (Kupchan, 2012). The "diversification" of other actors of global investment governance, such as international and regional organizations and multinational corporations should put more emphasis on defining the boundaries of their subsidiary responsibilities, by which they should support the sovereign states to maximize the "diversified" nature of the global investment regime. That is because lessons from the past suggest that conflicts may arise when the power boundaries between other actors and sovereign states are unclear, which could eventually lead to the failure of governance.

\section{The Rules of Global Investment Governance: Toward Greater Uniformity}

1) The overlapped status quo of the rules in global investment governance

In 2007, on the eve of the global financial crisis, the U.S. financial commentator Bill Gross predicted the advent of three major themes in the post-crisis era: greater regulation, deleverage and deglobalization (Gross, 2010). Gross's predications, at least in the global economic arena, have been materializing when one gives notice to an array of unprecedented changes like the U.S. that had withdrawn itself from the Trans-Pacific Partnerships (TPP) and Paris Agreement, suspended the Transatlantic Trade and Investment Partnership (TTIP) negotiations, demanded renegotiations of the North American Free Trade Agreement (NAFTA), and started to implement increasingly arbitrarily unilateral economic policies; the return of Latin American countries to the Calvo Doctrine; and many more countries that terminated or significantly revised provisions of investment agreements.

In the previous round of globalization, substantial achievement was made in trade and financial globalization. However, a gap remains between the integration of global investment and other areas of national economies, largely due to the severe "fragmentation" problems in investment. "Fragmented" global investment is attributable to overlaps and conflicts which exist between the various rule regimes of global investment governance. These rules of global investment governance are mainly comprised of bilateral investment agreements, regional and cross-regional free trade agreements and global, multilateral agreements. The complexity is compounded by informal principles and norms gradually established in global investment practices, foreign capital screening, and regulatory laws and regulations implemented by sovereign states.

Global investment governance is implemented under multiple international investment agreements which serve as the core body of rules. Investment-related provisions in bilateral investment agreements and free trade agreements have experienced rapid development, and now make up the majority of rules govern- 
ing global investment. Regional and cross-regional trade and investment agreements have also gained momentum, becoming increasingly important in the post-crisis era. However, since the failure of multilateral investment negotiations advocated by the OECD in 1991, the international community still lacks a systematic, uniform, binding and comprehensive set of rules. The intertwined, overlapping and even conflicting provisions of various investment agreements have produced a "spaghetti bowl" effect (Linn \& Tiomkin, 2006).

2) Improving the effectiveness of international investment regulations-from regionalism to multilateralism

The internal conflicts produced by inconsistent rules increase instability and undermine the overall value of these rules. Therefore, a set of unified, rather than "diversified", multilateral investment rules should be the solution. As a bottom line, further "diversity" in global investment rules should halt. WTO, UNCTAD, OECD and some key countries have attempted to advance an agreement at the multilateral level, but obviously with less-than-satisfactory outcomes. This is to be expected. The conflicts between global investment rules reflect a clash of different countries' notions on protecting investments. Compared with other areas in the global economy, global investment rules are more suited to serve as a tool of national strategic interests. In particular, given the fact that significant changes in the flows and overall structure of global investment have taken place in the 21st century, both developed and emerging economies have adjusted the functional goals of their investment rules (Caporaso, 1981).

With respect to the investment policies formulated by various countries, developing countries are more inclined to shift from investment protectionism to investment liberalism by increasing the "aggressiveness" of their national investment rules. Developed countries, however, tend to shift from investment liberalism to protectionism by emphasizing the "defensiveness" of investment rules. Developed and developing countries now tend to agree on provisions pertaining to expropriation and compensation, general exception clauses, investment protection treatments and investment transfers (Graham \& Marchick, 2006). But there is still considerable divergence in terms of the mode of investment entry and investment dispute settlement mechanisms (Congyan, 2009). These disputes reflect the divergent development stages, ideologies and development modes of the countries. Under such circumstances, only highly inclusive global or multilateral investment agreements can be broadly accepted. However, a template of such investment agreements usually means excessively rigid expressions and provisions.

The Doha Development Round gained little progress after its initiation in 2001 and was basically suspended after the 2007-8 economic crisis. There is an urgent need, however, to take up the cause again, and to make a set of rules to further advance market liberalization across the globe. The time seems ripe to many key actors. Members of regional economic organizations, and some regional trade agreements, such as the BRICS, ASEAN, TPP and TISA, have shown potential for pursuing cross-regional trade and investment agreements 
amid the stagnated multilateral negotiations on investment rules (Jachtenfuchs \& Kohler-Koch, 2003).

When global investment rules, previously dominated by bilateral investment agreements, shift to a framework dominated by global agreements, regional institutions start to provide facility for further development of the global economy. Beginning at a regional level, investment rules will gradually penetrate outward to other areas and eventually emerge as multilateral investment rules. In this way global economic integration runs in parallel with regional agreements (Qin, 2010).

Of course, there is bound to be conflict between regional regimes focusing on leadership, high standards and "deep liberalization" (such as those pursued by developed countries) and regimes focusing on economic development more suitable for a country's specific development stage-preferred by developing countries. Nonetheless, the core governance function of global investment rules should be achieved through the coordination of multiple sets of rules, which eventually works to bring an end to the chaos of global investment rules, reduce the complexity of these rules and strengthen their certainty and uniformity of through interactions of "diversified" rules.

\section{Conclusion}

According to the theory of the "inescapable political trilemma of the world economy" proposed by Dani Rodrik, a U.S. expert on political economics, it is impossible to have all three of the hyper-globalization, democratic policies and national self-determination at the same time (Rodrik, 2011). Countries can no longer count on the largely one-way flow of that characterized investment in an earlier, pre-crisis era. Countries that once were the destination for global investment are now home to businesses capable of looking beyond national borders into opportunities in the developed world. These investors are looking for regulatory regimes which better accommodate differences in national political and economic systems. Just as global governance systems regulating and promoting global trade and finance have evolved with, so also global investment governance must change with the times. Amid a broad recognition that the governance structure promoting and regulating foreign direct investment is an important part of stable, predictable global economic growth, the time has come to reform the system: 1) acknowledge and respect the diversity and the validity of different national values; 2 ) re-balance power distribution mechanism among the actors; and 3) increase uniformity across national regulatory regimes. Amid these reforms, the international community should continue advancing the construction of the multilateral global investment regimes in order to rejuvenate economic globalization and lift the global economy out of the predicaments still evident as a result of the financial crisis.

\section{Conflicts of Interest}

The author declares no conflicts of interest regarding the publication of this paper. 


\section{References}

Alonso, J. A., \& Ocampo, J. A. (2015). Global Governance and Rules for the Post-2015 Era: Addressing Emerging Issues in the Global Environment. London: Bloomsbury Publishing.

Alvarez, J. E. (2011). The Return of the State. Minnesota Journal of International Law, 20, 223.

Barnett, M., \& Duvall, R. (2004). Power in Global Governance (Vol. 98). Cambridge: Cambridge University Press. https://doi.org/10.1017/CBO9780511491207

Beaulac, S. (2003). The Social Power of Bodin's Sovereignty and International Law. Minnesota Journal of International Law, 4, 1.

Cai, C. Y. (2009). China-US BIT Negotiations and the Future of Investment Treaty Regime: A Grand Bilateral Bargain with Multilateral Implications. Journal of International Economic Law, 12, 457-506. https://doi.org/10.1093/jiel/jgp020

Cai, C. Y. (2018). The Leaving and Return of the State and the Future of International Law. Chinese Review of International Law, No. 4, 1.

Caporaso, J. A. (1981). Industrialization in the Periphery: The Evolving Global Division of Labor. International Studies Quarterly, 25, 347-384. https://doi.org/10.2307/2600579

Cassese, A. (2012). States: Rise and Decline of the Primary Subjects of the International Community. In The Oxford Handbook of the History of International Law (pp. 39-70). Oxford: Oxford University Press. https://doi.org/10.1093/law/9780199599752.003.0003

Cooper, R. J. (2004). The Beijing Consensus. Foreign Policy Centre. http://www.google.fr/url?sa=t\&rct=j\&q=\&esrc=s\&source=web\&cd=\&ved=2ahUKE wiSt7qgvYjqAhWvGaYKHY9FDKAQFjACegQIBRAB\&url=http\%3A\%2F\%2Fwww .chinaelections.org\%2Fuploadfile\%2F200909\%2F20090918021638239.pdf\&usg=AO vVaw0QdIl8pLbCV0kltSS2H7xv

Globerman, S., \& Shapiro, D. (2002). Global Foreign Direct Investment Flows: The Role of Governance Infrastructure. World Development, 30, 1899-1919. https://doi.org/10.1016/S0305-750X(02)00110-9

Graham, E. M., \& Marchick, D. (2006). US National Security and Foreign Direct Investment. Washington DC: Peterson Institute Press.

Gross, B. (2010). How to Play the Yield Curve. Investment News.

Haggard, S., \& Simmons, B. A. (1987). Theories of International Regimes. International Organization, 41, 491-517. https://doi.org/10.1017/S0020818300027569

Henkin, L. (1970). How Nations Behave. Law and Foreign Policy. VRÜ Verfassung und Recht in Übersee, 2, 387-392. https://doi.org/10.5771/0506-7286-1969-3-387

Hewson, M., \& Sinclair, T. J. (1999). Approaches to Global Governance Theory. Albany, NY: SUNY Press.

Hoekman, B. M., \& Mavroidis, P. C. (2015). Embracing Diversity: Plurilateral Agreements and the Trading System. World Trade Review, 14, 101-116. https://doi.org/10.1017/S1474745614000378

Hoffmann, S. (2002). Foreword to the Second Edition: Revisiting the Anarchical Society. In H. Bull (Ed.), The Anarchical Society: A Study of Order in World Politics (3rd ed., p. 11). Basingstoke: Palgrave.

Jachtenfuchs, M., \& Kohler-Koch, B. (2003). Governance and Institutional Development.

Keohane, R. O. (2001). Governance in a Partially Globalized World. American Political Science Review, 95, 1-13. https://doi.org/10.1017/S0003055401000016 
Kupchan, C. A. (2012). America's Place in the New World. New York Times, 7.

Linn, J. F., \& Tiomkin, D. (2006). The New Impetus towards Economic Integration between Europe and Asia. Asia Europe Journal, 4, 31-41. https://doi.org/10.1007/s10308-006-0046-6

Qin, Y. Q. (2010). International Society as a Process: Institutions, Identities, and China's Peaceful Rise. The Chinese Journal of International Politics, 3, 129-153.

Rodrik, D. (2011). The Globalization Paradox: Democracy and the Future of the World Economy. New York: WW Norton \& Company. https://doi.org/10.1355/ae28-3k

Sauvant, K. P. (2017). China Moves the G20 toward an International Investment Framework and Investment Facilitation. In J. Chaisse (Ed.), China's Three-Prong Investment Strategy: Bilateral, Regional, and Global Tracks (pp. 1-22). London: Oxford University Press. https://doi.org/10.1093/oso/9780198827450.003.0017

Schreuer, C. (2005). Calvo's Grandchildren: The Return of Local Remedies in Investment Arbitration. The Law \& Practice of International Courts and Tribunals, 4, 1-17. https://doi.org/10.1163/1571803053498899

Stephen, M. D. (2014). Rising Powers, Global Capitalism and Liberal Global Governance: A Historical Materialist Account of the BRICs Challenge. European Journal of International Relations, 20, 912-938. https://doi.org/10.1177/1354066114523655

Strange, S. (1996). The Retreat of the State: The Diffusion of Power in the World Economy. Cambridge: Cambridge University Press. https://doi.org/10.1017/CBO9780511559143

Unctad, U. (2017). World Investment Report 2017: Investment and the Digital Economy. In United Nations Conference on Trade and Development (p. 17). Geneva: United Nations.

$\mathrm{Xu}, \mathrm{C}$. (2010). A Commentary and Critical on the Recent International Investment Disputes Arbitration: To Introduce the Theory of Global Governance. The Jurist, 153, 143-153. https://doi.org/10.1093/cjip/poq007

Zakaria, F. (2013). The Rise of the Rest. In Debating a Post-American World (pp. 42-51). Abingdon-on-Thames: Routledge.

Zones, S. E. (2019). United Nations Conference on Trade and Development (UNCTAD). World Investment Report (WIR). 